\title{
PENINGKATAN HASIL BELAJAR DAN AKTIVITAS SISWA PADA MATERI ELASTISITAS BAHAN MELALUI MODEL PEMBELAJARAN DISCOVERY LEARNING
}

\author{
Cut Naimah* \\ Guru SMA Negeri 1 Meureudu \\ *Korespondensi: cut.naimah68@gmail.com
}

\begin{abstract}
Abstrak: Penelitian ini bertujuan untuk mengkaji sejauh mana model pembelajaran Discovery Learning dapat meningkatkan hasil belajar siswa. Subjek penelitian ini adalah siswa kelas XI IPA-5 semester 1 yang berjumlah 24 siswa, terdiri dari 10 siswa putra dan 14 siswa putri. Jenis penelitian yang digunakan adalah penelitian tindakan kelas (PTK) yang berlangsung dalam 2 siklus yang masing-masing siklus terdiri atas tahap perencanaan, tindakan, observsasi, dan refleksi. Data yang diperoleh dalam penelitian ini meliputi: hasil belajar siswa yang diambil dari pemberian soal tes pada akhir siklus, kemampuan guru dalam pembelajaran yang diambil dari lembar observasi, aktivitas siswa dalam pembelajaran yang diambil dari lembar observasi, dan data tentang refleksi siswa terhadap pembelajaran yang diambil dari angket pada setiap akhir pertemuan. Indikator keberhasilan pada penelitian ini adalah: (1) apabila $\geq 70 \%$ dari jumlah siswa berkategori tuntas dengan criteria tuntas belajaran apabila nilai hasil evaluasi pada siklus I, II, $\geq 65$, (2) apabila aktivitas siswa dalam pembelajaran $\geq 70 \%$ yang diukur dengan melihat lembar observasi siswa. Hasil penelitian pada siklus I menunjukkan rata-rata hasil belajar siswa sebesar 58,75 dan persentase ketuntasan belajar sebesar 60,71\%. Aktivitas siswa $63,64 \%$ persentase kemampuan guru $73,44 \%$. Sedangkan hasil penelitian pada siklus II rata-rata hasil belajar siswa sebesar 66,25 dan persentase ketuntasan belajar sebesar 71,43\% dan aktivitas siswa 75,00\%. Dari penelitian ini diperoleh kesimpulan bahwa dengan menggunakan model pembelajaran Discovery Learning dapat meningkatkan hasil belajar dan aktivitas siswa kelas XI MIPA-5 semester 1 pada materi elastisitas bahan.
\end{abstract}

Kata kunci: Discovery Learning, Hasil Belajar, Aktivitas Siswa

\section{IMPROVING OF STUDENT LEARNING OUTCOMES AND ACTIVITIES IN THE ELASTICITY OF MATERIALS THROUGH DISCOVERY LEARNING LEARNING MODELS}

\begin{abstract}
Abstrak: This study aims to examine the extent to which the Discovery Learning learning model can improve student learning outcomes. The subjects of this study were 24 students of class XI IPA-5 semester 1, consisting of 10 male students and 14 female students. The type of research used is classroom action research (PTK) which takes place in 2 cycles, each of which consists of planning, action, observation, and reflection stages. The data obtained in this study include: student learning outcomes taken from giving test questions at the end of the cycle, the teacher's ability in learning taken from the observation sheet, student activities in learning taken from the observation sheet, and data about students' reflections on the learning taken from the questionnaire at the end of each meeting. The indicators of success in this study are: (1) if $\geq$ $70 \%$ of the total students are categorized as complete with learning completion criteria if the evaluation results in cycles $I, I I, \geq 65$, (2) if student activity in learning is $\geq 70 \%$ as measured by look at the student observation sheet. The results of the study in the first cycle showed that the average student learning outcomes were 58.75 and the percentage of completeness learning
\end{abstract}


was $60.71 \%$. Student activity $63.64 \%$ percentage of teacher ability $73.44 \%$. While the results of the research in the second cycle the average student learning outcomes of 66.25 and the percentage of completeness of learning was $71.43 \%$ and student activity was $75.00 \%$. From this study, it was concluded that using the Discovery Learning learning model can improve learning outcomes and student activity in class XI MIPA-5 semester 1 on material elasticity of material.

\section{Keywords: Discovery Learning, Learning Outcomes, Student Activities}

\section{PENDAHULUAN}

Fisika merupakan ilmu yang pada awalnya diperoleh dan dikembangkan berdasarkan percobaan (induktif) namun pada perkembangan selanjutnya fisika juga diperoleh dan dikembangkan berdasarkan teori (deduktif). Fisika adalah ilmu yang mencari jawaban atas pertanyaan apa, mengapa, dan bagaimana gejala-gejala, sifat, perubahan, dinamika, dan energetika zat. Ada dua hal yang berkaitan dengan fisika yang tidak terpisahkan, yaitu fisika sebagai produk (pengetahuan fisika yang berupa fakta, konsep, prinsip, hukum, dan teori) temuan ilmuwan dan fisika sebagai proses (kerja ilmiah). Menurut (Siswono, 2017) Pembelajaran Fisika yang sebagian besar fenomena alam dituntut untuk memahami pengetahuan secara kontekstual. Oleh sebab itu, pembelajaran fisika dan penilaian hasil belajar fisika harus memperhatikan karakteristik ilmu fisika sebagai proses dan produk.

Menurut (Siswono, 2017) pembelajaran Fisika yang sebagian besar fenomena alam dituntut untuk memahami pengetahuan secara kontekstual. Hal ini memerlukan pendekatan sains secara ilmiah untuk meningkatkan dan mengembangkan pengetahuan yang dialami siswa. Selanjutnya (Sutrisno, 2017) menyatakan bahwa dalam pembelajaran fisika tidak hanya disampaikan hukum-hukum, teori, sistem, model atau metode pengetahuan yang sudah siap, tetapi harus pula diupayakan tercapainya sikap positip siswa terhadap ilmu fisika. Dengan demikian siswa akan mampu dan akan siap berpikir kreatif, mengadakan analisis dan memecahkan masalah. (Puspitasari et al., 2017) menyatakan bahwa konsepkonsep fisika memang rumit dan diperlukan keterampilan matematika untuk menyelesaikan soal-soal fisika. Meskipun demikian yang lebih diperlukan adalah keterampilan belajar agar siswa mampu memproses informasi dan mengingatnya kembali tanpa keliru.

Seiring dengan dicanangkannya kurikulum 2013, kita tidak bisa lagi mempertahankan paradigma lama yaitu guru merupakan pusat kegiatan belajar di kelas (teacher center). Tetapi hal ini nampaknya masih banyak diterapkan di ruang-ruang kelas dengan alasan pembelajaran seperti ini adalah yang paling praktis dan tidak menyita waktu. Hal ini sesuai dengan pernyataan (Alawiyah, 2013) yang menyatakan bahwa Pada kurikulum 2013 peran guru berkurang dibandingkan peran guru pada KBK dan KTSP yaitu sebagai pelaksana teknis. Hal ini membuka peluang bagi guru untuk dapat mengoptimalkan efektivitas pembelajaran di kelas dalam rangka meningkatkan kualitas pendidikan melalui peningkatan kompetensi guru serta optimalisasi guru dalam pembelajaran.

Dalam proses pembelajaran fisika masih sering dijumpai adanya kecenderungan siswa yang tidak mau bertanya kepada guru meskipun mereka sebenarnya belum mengerti tentang materi yang disampaikan. Tetapi ketika guru menanyakan bagian mana yang belum mereka mengerti seringkali siswa hanya diam, dan setelah guru memberikan soal latihan barulah guru mengerti bahwa sebenarnya ada bagian dari materi yang belum dimengerti siswa.

Kondisi kelas XI IPA-5 SMA Negeri 1 Meureudu, berjumlah 24 siswa relatif heterogen, baik dari segi ekonomi, kemampuan akademik, kreatifitas maupun sarana yang dimilikinya. Selain itu berdasarkan pengalaman guru, didapati suasana kelas yang monoton pada setiap pembelajaran dilaksanakan, terlihat dari rendahnya kemampuan siswa untuk bertanya dan menjawab pertanyaan, nilai hasil belajar rendah, dengan persentase siswa yang tuntas belajar hanya berkisar antara 30 - 50\% saja pada setiap ulangan dilaksanakan. 
Berdasarkan pengalaman, hasil observasi dan diskusi dengan beberapa guru mata pelajaran fisika, rendahnya hasil belajar siswa selama ini disebabkan karena proses pembelajaran fisika masih didominasi oleh guru sehingga keaktifan siswa dalam kelas masih kurang. Dalam melaksanakan proses belajar mengajar diperlukan langkah-langkah sistematis untuk mencapai tujuan yang telah ditentukan. Hal yang harus dilakukan adalah dengan menggunakan model yang cocok dengan kondisi siswa agar siswa dapat berpikir kritis, logis, dan dapat memecahkan masalah dengan sikap terbuka, kreatif, dan inovatif. Dalam pembelajaran kurikulum 2013 dikenal berbagai model pembelajaran yang sesuai salah satunya adalah pembelajaran degan model Discovery Learning. Menurut (Akhmad Yazidi, 2014) Discovery Learning adalah model memahami konsep, arti dan hubungan, melalui proses intuitif untuk akhirnya sampai kepada suatu kesimpulan. (Wahjudi, 2015) menambahkan bahwa model pembelajaran Discovery Learning mengarahkan peserta didik untuk memahami konsep, arti, dan hubungan, melalui proses intuitif untuk akhirnya sampai kepada suatu kesimpulan. Selain itu, menurut (Putrayasa et al., 2014) model pembelajaran discovery learning berpengaruh terhadap hasil belajar siswa.

Dalam penelitian ini dipilih materi pokok elastisitas karena selain masih rendahnya hasil belajar, juga merupakan materi yang sifatnya kontekstual. Materi pokok ini memungkinkan siswa untuk belajar menemukan konsep, rumus secara kreatif melalui kerja praktik dan diskusi kelompok. Berdasarkan uraian tersebut melalui penelitian ini diujicobakan model pembelajaran Discovery Learning untuk meningkatkan hasil belajar dan aktivitas siswa kelas XI IPA-5 semester I SMA Negeri 1 Meureudu Kabupaten Pidie Jaya khususnya materi elastisitas.

\section{METODE}

Jenis penelitian ini adalah penelitian tindakan kelas (PTK) yang dilaksanakan di SMA Negeri 1 Meureudu Pidie Jaya, selain itu salah satu tujuan dari penelitian ini adalah untuk memperbaiki proses pembelajaran fisika pada materi elastisitas bahan. Subyek penelitiannya adalah siswa-siswi kelas XI MIPA-5 SMA Negeri 1 Meureudu Pidie Jaya yang berjumlah 24 orang siswa, yang terdiri dari 10 lakilaki dan 14 orang siswa perempuan. Penelitian tindakan kelas ini berlangsung dalam semester 1 terdiri dari 2 siklus. Setiap siklus 1 kali tatap muka. lokasi waktu untuk setiap tatap muka adalah 4 jam pelajaran. Prosedur dalam penelitian tindakan kelas ini meliputi tahap perencanaan, pelaksanaan tindakan, pengamatan dan refleksi. Tahapan tersebut disusun dalam 2 siklus.

Sumber data dalam penelitian ini adalah siswa sebagai subyek penelitian. Data yang dikumpulkan dari siswa meliputi data hasil observasi dan tes tertulis. Tes tertulis dilaksanakan pada setiap akhir siklus atas materi elastisitas bahan.

\section{HASIL DAN PEMBAHASAN}

Dalam perencanaan tindakan kelas ini, peneliti telah menyusun rencana pelaksanaan pembelajaran pada materi elastisitas bahan, menyiapkan instrumen penelitian (lembar observasi siswa, kuisioner angket refleksi siswa, lembar tes hasil belajar siswa), menyiapkan sumber belajar berupa materi diskusi (hand out); lembar kerja peserta didik (LKPD), merancang pembentukan kelompok, setiap kelompok terdiri dari 4 siswa dengan memperhatikan penyebaran kemampuan siswa berdasarkan nilai ulangan materi sebelumnya, dan mengembangkan skenario pembelajaran Discovery Learning sebagaimana RPP terlampir.

Selanjutnya, ketika peneliti melakukan tindakan pada siklus I, guru melakukan apersepsi, memberikan motivasi untuk mengarahkan siswa memasuki materi elastisitas bahan, menyampaikan tujuan pembelajaran yang akan dicapai, menjelaskan materi pelajaran secara ringkas $( \pm 15$ menit), menjelaskan langkah kerja model pembelajaran Discovery Learning , mengarahkan siswa agar duduk sesuai kelompok yang ditentukan. Guru membagikan LKPD, hand out kepada setiap siswa sebagai bahan yang akan dipelajari. Siswa bersama kelompoknya berdiskusi mengerjakan LKPD, setiap kelompok 
diharuskan memastikan semua anggotanya dapat memahami diskusi tersebut. Pada saat siswa berdiskusi, guru berkeliling mengarahkan dan membimbing bila ada kelompok yang mengalami kesulitan, serta memotivasi seluruh siswa untuk berpartisipasi dalam diskusi kelompok. Setelah waktu diskusi selesai, siswa mempresentasikan hasil diskusi kelompok. Para siswa dari tiap kelompok sama juga bersiap-siap memberikan presentasi ataupun masukan. Tiap kelompok memperhatikan dan bila kurang jelas diberi kesempatan bertanya, jika terjadi perbedaan pendapat maka kelompok lain diberi kesempatan untuk menanggapi (memberi masukan dan jawaban). Selanjutnya, dilakukan diskusi kelas untuk membuat kesimpulan di akhir kegiatan, sekaligus menentukan kelompok mana yang terbaik menurut pengamatan siswa dengan memberi kesempatan pada masing-masing ketua kelompok menilai hasil kerja kelompok.

Peneliti memberikan hadiah kecil berupa pensil dan menepuk tangan bersama siswa pada kelompok terbaik. Pada saat yang sama, kolaborator melakukan pengamatan dengan mengisi instrumen yang sudah disiapkan meliputi: pengamatan kegiatan siswa saat kegiatan belajar mengajar. Di akhir siklus, peneliti memberikan tes hasil belajar dan meminta siswa mengisi angket refleksi terhadap pembelajaran yang telah dilakukan. Hasil pengamatan aktivitas siswa pada pertemuan siklus I dapat dilihat pada tabel berikut.

Tabel 1. Hasil Observasi Aktivitas Siswa Pertemuan Siklus I

\begin{tabular}{|c|c|c|c|}
\hline No. & Aktivitas & $\begin{array}{l}\text { Persentase / } \\
\text { Penilaian }\end{array}$ & Arti \\
\hline 1. & (1) & $\begin{array}{l}50 \%-75 \% \\
\text { Baik }\end{array}$ & $\begin{array}{l}2 \text { - } 3 \text { kelompok memperhatikan penjelasan guru, } \\
\text { mereka sudah mulai terbiasa dengan metode } \\
\text { pembelajaran yang sedang dilaksanakan. }\end{array}$ \\
\hline 2. & $(2)$ & $\begin{array}{l}<25 \% \\
\text { Kurang }\end{array}$ & Masih sedikit yang mau bertanya tentang materi. \\
\hline 3. & (3) & $\begin{array}{l}50 \%-75 \% \\
\text { Baik }\end{array}$ & $\begin{array}{l}\text { Siswa mulai dapat mengkondisikan dirinya ke } \\
\text { dalam kelompok yang telah dibentuk. }\end{array}$ \\
\hline 4. & (4) & $\begin{array}{l}50 \%-75 \% \\
\text { Baik }\end{array}$ & $\begin{array}{l}\text { Siswa mulai menunjukkan antusias terhadap } \\
\text { pembelajaran setelah dimotivasi oleh guru. }\end{array}$ \\
\hline 5. & $(5)$ & $\begin{array}{l}50 \%-75 \% \\
\text { Baik }\end{array}$ & $\begin{array}{l}\text { Sifat saling membantu sudah mulai tampak } \\
\text { sehingga banyak siswa yang kemampuannya } \\
\text { kurang, berani untuk bertanya kepada temannya }\end{array}$ \\
\hline 6. & (6) & $\begin{array}{l}50 \%-75 \% \\
\text { Baik }\end{array}$ & $\begin{array}{l}\text { Siswa yang kemampuannya lebih, sudah mau } \\
\text { bekerjasama dengan teman sekelompoknya. }\end{array}$ \\
\hline 7. & (7) & $\begin{array}{l}25 \%-50 \% \\
\quad \text { Cukup }\end{array}$ & $\begin{array}{l}\text { Hanya sebagian siswa berpartisipasi dalam } \\
\text { diskusi kelompok. }\end{array}$ \\
\hline 8. & $(8)$ & $\begin{array}{l}25 \%-50 \% \\
\text { Cukup }\end{array}$ & $\begin{array}{l}\text { Masih sedikit kelompok yang mampu } \\
\text { mempresentasikan pekerjaannya dengan baik. }\end{array}$ \\
\hline 9. & (9) & $\begin{array}{l}25 \%-50 \% \\
\text { Cukup }\end{array}$ & $\begin{array}{l}2-3 \text { kelompok yang memberikan tanggapan, } \\
\text { bertanya atau menyanggah yang dipresentasikan. }\end{array}$ \\
\hline 10. & $(10)$ & $\begin{array}{l}25 \%-50 \% \\
\text { Baik }\end{array}$ & $\begin{array}{l}2 \text { - } 3 \text { kelompok yang turut memberi pendapat } \\
\text { dalam membuat kesimpulan terhadap hasil } \\
\text { pemecahan masalah. }\end{array}$ \\
\hline 11. & $(11)$ & $\begin{array}{l}50 \%-75 \% \\
\text { Baik }\end{array}$ & $\begin{array}{l}\text { Sudah banyak yang senang terhadap } \\
\text { penghargaan oleh guru. }\end{array}$ \\
\hline
\end{tabular}

Dari hasil di atas, persentase aktivitas siswa dalam pembelajaran sebesar 63,64\% dengan skor terendah 1 dan skor tertinggi 3. 
Setelah dilakukan analisis data hasil tes siklus I dengan materi elastisitas bahan diperoleh nilai rata-rata siswa sebesar 58,75. Siswa yang tuntas sebanyak 17 anak $(60,71 \%)$, siswa yang tidak tuntas sebanyak 8 anak $(39,29 \%)$ dengan nilai tertinggi 90 dan nilai terendah 20.

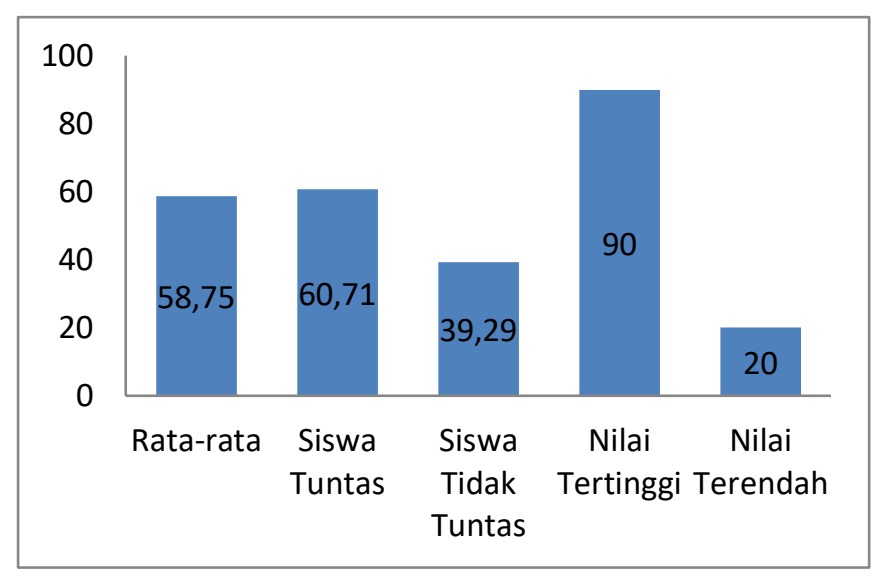

Gambar 1. Grafik Perolehan Hasil Tes Siklus I

Pada siklus I, dari setiap pertemuan menunujukkan peningkatan aktifitas belajar siswa. Seperti meningkatnya antusias dan motivasi siswa dalam mengikuti pembelajaran, karena dorongan dan pemberian motivasi oleh guru. Untuk kerja kelompokpun menunjukkan aktivitas, seperti meningkatnya diskusi dan tanya jawab antar teman dalam kelompok, serta memberi pendapat tentang hasil yang dipresentasikan. Selain itu dalam mengkaji ulang/melakukan evaluasi dan membuat kesimpulan juga semakin meningkat namun ini belum menunujukkan aktivitas yang optimal sesuai dengan yang diharapkan sehingga perlu ditingkatkan.

Berdasarkan hasil lembar observasi aktivitas siswa, keaktifan siswa 63,64\%. Hasil ini masih jauh dari indikator kaberhasilan yang ditetapkan sebanyak $70 \%$. Hal ini disebabkan antara lain siswa masih kurang percaya diri dalam mengemukakan pendapat maupun bertanya, dan masih canggung untuk bekerja dalam kelompok. Selain itu pengawasan tingkah laku siswa dalam melakukan diskusi kelompok masih kurang, terlihat masih adanya siswa yang tidak memperhatikan penjelasan guru.

Kelompok yang ditunjuk untuk menyajikan hasil diskusi masih terlihat ragu-ragu dan kurang menguasai materi, suaranya juga kurang keras. Dengan kurangnya penguasaan materi siswa penyaji, berarti pembelajaran Discovery Learning belum terlaksana dengan baik. Karena, dalam pelaksanaan pembelajaran Discovery Learning siswa berdiskusi dan menyatukan pendapat mereka, dan memastikan semua anggota kelompok paham dengan diskusi tersebut. Siswa yang mempunyai kemampuan lebih, diharapkan untuk mengajari teman sekelompok yang kemampuannya kurang.

Kekurangan aktivitas dalam pembelajaran tersebut perlu adanya perbaikan dengan memberikan dorongan motivasi kepada siswa untuk bersungguh-sungguh dalam mengerjakan tugas, menyatukan pendapat, tidak boleh mengganggu teman serta melakukan diskusi secara aktif dan memberi pujian bagi siswa yang bertanya dan menjawab pertanyaan. Guru harus mampu memberi perhatian serta motivasi terhadap kegiatan siswa dalam kelompoknya. Permasalahan ini akan diupayakan perbaikan pada siklus II.

Untuk hasil belajar siswa dari Gambar 1 diperoleh rata-rata hasil belajar siswa sebesar 58,75. Ketuntasan belajar klasikal sebesar 60,71\% atau sebanyak 17 anak tuntas belajar dengan mendapatkan nilai $\geq 65$. Dengan demikian hasil belajar belum tercapai secara optimal, oleh karena itu perlu diadakan upaya perbaikan pada siklus 2 dengan memotivasi siswa untuk lebih aktif dalam pembelajaran, dan bila perlu dengan memberikan penghargaan yang berbentuk benda, seperti memberikan bolpoin pada semua 
anggota kelompok terbaik, menyediakan sumber belajar berupa fotokopi materi atau meminjamkan buku ajar. Hasil pengamatan aktivitas siswa pada siklus II dapat dilihat pada tabel 2. berikut.

Tabel 2. Hasil Observasi Aktivitas Siswa Siklus II

\begin{tabular}{|c|c|c|c|}
\hline No. & Aktivitas & $\begin{array}{l}\text { Persentase } \\
\text { / Penilaian }\end{array}$ & Arti \\
\hline 1. & (1) & $\begin{array}{l}50 \%-75 \% \\
\text { Baik }\end{array}$ & $\begin{array}{l}3-4 \text { kelompok memperhatikan penjelasan } \\
\text { guru, mereka sudah mulai terbiasa dengan } \\
\text { metode pembelajaran yang sedang } \\
\text { dilaksanakan. }\end{array}$ \\
\hline 2. & (2) & $\begin{array}{l}25 \%-50 \% \\
\text { Cukup }\end{array}$ & $\begin{array}{l}3 \text { - } 4 \text { kelompok sudah mau bertanya tentang } \\
\text { materi. }\end{array}$ \\
\hline 3. & (3) & $\begin{array}{c}>75 \% \\
\text { Sangat Baik }\end{array}$ & $\begin{array}{l}\text { Siswa sudah dapat mengkondisikan dirinya } \\
\text { ke dalam kelompok yang telah dibentuk. }\end{array}$ \\
\hline 4. & (4) & $\begin{array}{l}50 \%-75 \% \\
\text { Baik }\end{array}$ & $\begin{array}{l}\text { Siswa sudah menunjukkan antusias terhadap } \\
\text { pembelajaran setelah dimotivasi oleh guru. }\end{array}$ \\
\hline 5. & $(5)$ & $\begin{array}{l}>75 \% \\
\text { Sangat Baik }\end{array}$ & $\begin{array}{l}\text { Kerjasama antar kelompok sudah terlihat } \\
\text { karena siswa bersama-sama menyatukan } \\
\text { pendapat dan berusaha mencari jawaban } \\
\text { yang benar. }\end{array}$ \\
\hline 6. & (6) & $\begin{array}{l}50 \%-75 \% \\
\text { Baik }\end{array}$ & $\begin{array}{l}\text { Siswa yang kemampuannya lebih, mau } \\
\text { bekerjasama dengan teman sekelompoknya. }\end{array}$ \\
\hline 7. & (7) & $\begin{array}{l}50 \%-75 \% \\
\text { Baik }\end{array}$ & $\begin{array}{l}\text { Hampir semua siswa berpartisipasi dalam } \\
\text { diskusi kelompok. }\end{array}$ \\
\hline 8. & (8) & $\begin{array}{l}50 \%-75 \% \\
\text { Baik }\end{array}$ & $\begin{array}{l}3-4 \text { kelompok sudah mampu } \\
\text { mempresentasikan pekerjaannya dengan } \\
\text { baik. }\end{array}$ \\
\hline 9. & (9) & $\begin{array}{l}50 \%-75 \% \\
\text { Baik }\end{array}$ & $\begin{array}{l}3 \text { - } 4 \text { kelompok yang memberikan } \\
\text { tanggapan, bertanya atau menyanggah yang } \\
\text { dipresentasikan. }\end{array}$ \\
\hline 10. & (10) & $\begin{array}{l}25 \%-50 \% \\
\text { Baik }\end{array}$ & $\begin{array}{l}3-4 \text { kelompok yang turut memberi } \\
\text { pendapat dalam membuat kesimpulan } \\
\text { terhadap hasil pemecahan masalah. }\end{array}$ \\
\hline 11. & (11) & $\begin{array}{l}50 \%-75 \% \\
\text { Baik }\end{array}$ & $\begin{array}{l}\text { Sudah banyak yang senang terhadap } \\
\text { penghargaan oleh guru. }\end{array}$ \\
\hline
\end{tabular}

Dari hasil di atas, persentase aktivitas siswa dalam pembelajaran sebesar 75,00\% dengan skor terendah 2 dan skor tertinggi 4.

Setelah dilakukan analisis data hasil tes siklus II dengan materi minyak bumi diperoleh nilai ratarata siswa sebesar 66,25. Siswa yang tuntas sebanyak 20 anak $(71,43 \%)$, siswa yang tidak tuntas sebanyak 5 anak $(28,57 \%)$ dengan nilai tertinggi 100 dan nilai terendah 35 . 


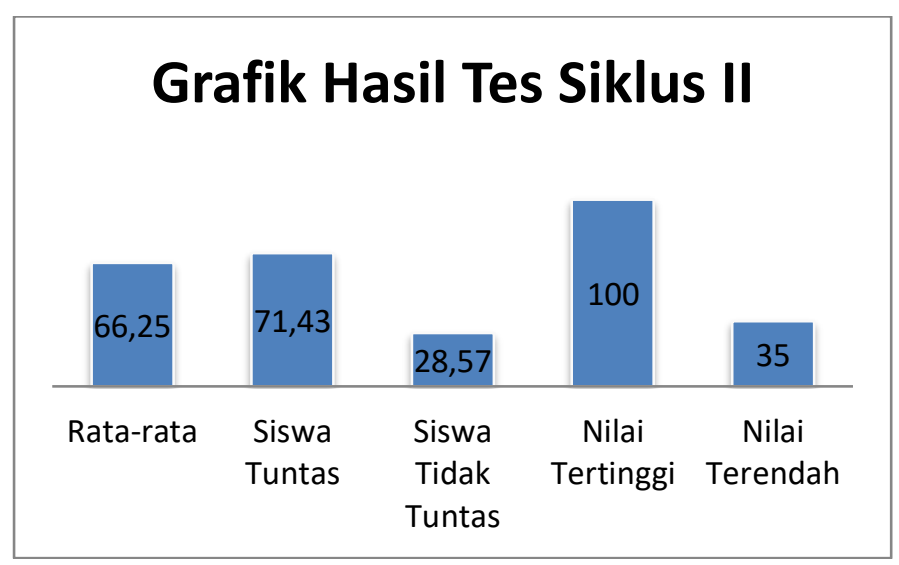

Gambar 2. Grafik Perolehan Hasil Tes Siklus II

Pada siklus II aktivitas siswa lebih meningkat lagi dibandingkan dengan siklus I. Ditandai dengan perolehan persentase hasil observasi yang tinggi yaitu sebesar 75,00\%. Hal ini menunjukkan siswa dalam melakukan aktivitas yang diharapkan lebih banyak dibandingkan dengan siklus I. Siswa sudah lebih terarah pada kerjasama kelompok, meningkatnya diskusi dan tanya jawab dalam kelompok serta lebih berani dalam mengungkapkan pendapatnya, ditandai dengan adanya siswa yang bertanya serta menjawab pertanyaan. Siswa juga telah bekerja sama dengan kelompoknya secara baik, siswa yang pandai sudah mulai menularkan idenya kepada siswa lain yang masih kurang, sehingga semua anggota kelompok memahami diskusi. Hal ini sudah sesuai dengan apa yang diharapkan dalam pembelajaran Discovery Learning bahwa siswa menyatukan pendapatnya terhadap jawaban pertanyaan / tugas dari guru dan meyakinkan tiap anggota kelompok mengetahui jawaban itu. Sejalan dengan (Nugrahaeni et al., 2017) yang menyatakan bahwa penerapan pembelajaran dengan menggunakan model Discovery Learning terbukti efektif dalam meningkatkan hasil belajar siswa dan keterampilan berpikir kritis siswa.

Hasil belajar siswa pada siklus II terdapat peningkatan. Hal ini dapat terlihat dari Gambar 2 diperoleh rata-rata hasil tes yang diberikan kepada siswa pada siklus II adalah sebesar 66,25. Ketuntasan belajar secara klasikal sebesar $71,43 \%$ atau sebanyak 20 anak memperoleh nilai $\geq 6,5$. Dengan demikian hasil belajar pada siklus II ini sudah sesuai dengan indikator keberhasilan yang ditetapkan, sehingga tidak perlu dilakukan siklus selanjutnya. Sehingga dapat dikatakan bahwa model pembelajaran discovery learning sangat cocok diterapkan dalam meningkatkan hasil belajar siswa dibandingkan dengan model pembelajaran lainnya. Sejalan dengan pernyataan (Sappaile et al., 2018) yang menyatakan bahwa model pembelajaran discovery learning lebih baik daripada model pembelajaran langsung.

\section{PENUTUP}

Berdasarkan hasil penelitian dan pembahasan diatas dapat disimpulkan sebagai bahwa hasil belajar dan aktiviras siswa kelas XI. IPA-5 semester 1 SMA Negeri 1 Meureudu Kabupaten Pidie Jaya pada materi elastisitas bahan dapat ditingkatkan dengan model pembelajaran Discovery Learning , ditunjukkan oleh peningkatan rata-rata nilai tes akhir siswa dari 58,75 pada siklus I menjadi 66,25 pada siklus II, dan ketuntasan belajar siswa meningkat dari $60,71 \%$ pada siklus I menjadi $71,43 \%$ pada siklus II.

\section{DAFTAR PUSTAKA}

Akhmad Yazidi. (2014). Memahami Model-Model Pembelajaran Dalam Kurikulum 2013 (The Understanding Of Model Of Teaching In Curriculum 2013). Jurnal Bahasa, Satra, Dan 


\section{Pembelajarannya.}

Alawiyah, F. (2013). Peran Guru Dalam Kurikulum 2013 The Role Of Teacher In Curricullum 2013. Aspirasi.

Nugrahaeni, A., Redhana, I. W., \& Kartawan, I. M. A. (2017). Penerapan Model Pembelajaran Discovery Learning Untuk Meningkatkan Kemampuan Berpikir Kritis Dan Hasil Belajar Kimia. Jurnal Pendidikan Kimia Indonesia. Https://Doi.Org/10.23887/Jpk.V1i1.12808

Puspitasari, D., Prastowo, S., \& Prihandono, T. (2017). Analisis Pemahaman Konsep Siswa Tentang Elastisitas Di Kelas Xi Sma. Seminar Nasional Pendidikan Fisika 2017, Issn : 2527-5917.

Putrayasa, I. M., Syahruddin, H., \& Mergunayasa, I. G. (2014). Pengaruh Model Pembelajaran Discovery Learning Dan Minat Belajar Terhadap Hasil Belajar Ipa Siswa. Jurnal Mimbar Pgsd Universitas Pendidikan Ganesha.

Sappaile, B. I., Djaman, N., Ba'ru, Y., Kadir, K., \& Darwis, M. (2018). Penerapan Model Pembelajaran Discovery Learning Terhadap Hasil Belajar Matematika Ditinjau Dari Minat Belajar Siswa Smp Negeri Di Kota Rantepao. Journal Of Medives : Journal Of Mathematics Education Ikip Veteran Semarang. Https://Doi.Org/10.31331/Medives.V2i2.597

Siswono, H. (2017). Analisis Pengaruh Keterampilan Proses Sains Terhadap Penguasaan Konsep Fisika Siswa. Momentum: Physics Education Journal. Https://Doi.Org/10.21067/Mpej.V1i2.1967

Sutrisno. (2017). Problem Based Learning Sebagai Suatu Strategi Pembelajaran Untuk MenumbuhKembangkan Atmosfer Kebebasan Intelektual. Quantum: Jurnal Inovasi Pendidikan Sains.

Wahjudi, E. (2015). Penerapan Discovery Learning Dalam Pembelajaran Ipa Sebagai Upaya Untuk Meningkatkan Hasil Belajar Siswa Kelas Ix-I Di Smp Negeri 1 Kalianget. Jurnal Lentera Sains (Lensa). 